\title{
CONCEPTUAL DELIMITATIONS REGARDING THE SALES FORECASTING METHODS. CASE STUDY FOR THE SEASONAL COEFFICIENT METHOD
}

\author{
Simona Elena Dragomirescu \\ "Vasile Alecsandri" University of Bacău \\ dragomirescu@ub.ro \\ Daniela Cristina Solomon \\ "Vasile Alecsandri” University of Bacău \\ daniela.solomon@ub.ro
}

\begin{abstract}
One of the most important stages in the budget drafting process is the sales forecasting. As a matter of fact, the sales affect the whole activity of a company, their variation being considered the main risk factor for the performance and the financial position of the company. Sales forecasting starts with analyzing the turnover over a longer period of time. It includes all the studies and calculations made in order to determine the potential market to which the company can get access, as well as the part of it that the company is estimated to cover. There are several methods for planning the amount of sales, each company being able to choose one or more such methods. All the sales forecasting methods have advantages and disadvantages; however, in practice it was proved that most large companies use a combination of several methods. However, when there are seasonal variations each year, the seasonal coefficient method is used in order to forecast the sales. The exemplification of this method is done on the level of an production industrial company.
\end{abstract}

Keywords

sales budget; sales forecasting; sales forecasting methods; seasonal coefficient method

\section{JEL Classification}

M41

\section{Sales forecasting - the starting point in drafting the budget}

In the budget drafting process, the starting point is forecasting the sales activity. The sales budget is the forecast expressed in numbers for the company sales on types of products and services and/or groups, on quantities and prices, on destinations and periods of time. They will be regrouped on clients, regions, countries. The importance of drafting such a budget is given:

- on long term, by setting the investment plan and the financing plan;

- on medium term, by setting the expense budget pertaining to advertising and promotion;

- on short term, by determining the production level, the procurement plan, improving the workforce.

In this context, we consider the sales budget as a support budget allowing the coordination of the other budgets.

Considering the time span criterion, there can be long-term or short-term forecasting. Long-term forecasting is based on research done not only on the goods and services existing on the market, but also on the analysis of the existing or the virtual market needs in that particular field. On short term, the forecasting is limited to allowing for the external constraints imposed by the market, the competition or by the purchasing 
power, as well as the internal constraints imposed by the company's trade policy, the trade methods and by the current production capacity. In order to ensure the long-term success of the company, it is vital to have an accurate sales forecast. In the context of the information society, the modern organization cannot survive without having realtime information, from both inside and outside its (Bucur, 2007). Under these conditions, marketing studies will be done on the external environment (the general economic situation, the company's position compared to the competition, the price level, the clients' behavior and so on), as well as on the internal environment (the normal production capacity, the trade policy, the pricing policy etc.).

\section{Presentation of the sales forecasting methods, according to the specialized literature}

The estimation of sales requires setting the level of the future sales, from the point of view of quality and value, considering the trends and the restrictions imposed to the company, as well as the general policy of the company. In order to avoid the empiricism of the forecasts, it is necessary to carry out some rational research. Thus, the data processing and analysis must be done based on a logical, rational method. There are several methods for planning the sales volume, each company being able to choose one or more of them. As all the methods have both advantages and disadvantages, in practice it was ascertained that most great companies use a combination of these methods.

A series of methods are presented in the specialized literature, among which we mention:

- the causal approach, when several variables with causal effect on the prospective sales are identified;

- the noncausal approach, according to which the planning is done by analyzing the data of the previous periods of time, based on the idea that the future results will follow the trend of the previous results;

- the direct method, which requires certain simple projections, without taking into consideration the trends of the industry within which the company functions and competes;

- the indirect method, as the opposite of the direct method, starts from the trends of the industry in order to forecast the percentage rate that the company aims to reach within the industry;

- the assessment methods (the manager's opinion method or the information achieved from the sales staff or from the sales supervisors); the easiest forecasting methods, are based on the manager's opinions, who collects the information directly from the executive board members, or on the projections of the sales staff/ sales department managers, the ones who get information concerning the demand directly from the consumers; some of the advantages of applying the assessment methods are that they are less time-consuming and less expensive; a great disadvantage is that they are based on opinions and not on facts;

- the statistical methods, as opposed to the assessment methods, are based on technical knowledge and on statistical applications; examples of such methods: the trend analysis, the analysis of the correlations, the preset goal method, the industry analysis method, the production line analysis, the analysis of the final user.

According to the nature of the factors considered to be the origin of the phenomenon, the sales forecasting methods are divided into:

- qualitative methods, which research the phenomena and try to explain them based mostly on intuition (investigations based on questionnaires, marketing studies or polls and so on); 
- quantitative methods, which start for statistical data expressed in figures when setting the forecasts. In this category are included methods such as the linear adjustment, the correlation, the mobile average method, the seasonal coefficient method. The linear adjustment and the correlation can be applied in researching the general trends of the sales evolution, when the trend is linear. In those cases in which the linear adjustment is not suitable for setting the trend, the mobile average method can be applied, which is based on the idea that the forecast pertaining to a month or a year is an average of the sales for the previous months, any contingent fluctuations counterbalancing each other. When there are seasonal variations every year, in order to forecast the sales we resort to the seasonal coefficient method.

\section{Theoretical aspects concerning the seasonal coefficient method}

In case there are seasonal variations every year, the estimation of the sales volume from the point of view of value and quantity is achieved using the seasonal coefficient method. The range of the seasonal variations is generally proportional to the trend.

The seasonal coefficients can be set as trend reports, chains of reports, simple methods. Thus:

- $\quad$ the trend report method requires setting some monthly average values of the real value reports and of the adjusted values calculated using method of least squares;

- the chain of reports method requires certain more complex stages, this method pertaining to the exponential trend cases;

- the simple methods require determining the monthly average values reported to the average of all the months.

No matter which method is used, the seasonal coefficients calculated will be used to influence the monthly adjustment equation.

Case study concerning the sales forecasting in the case of a production industrial company, using the seasonal coefficient method

Within the "ALFA" industrial company, the sales evolution in the case of product " $\mathrm{X}$ ", for the period of time $2010-2013$ is as follows:

Table 1 Historical data concerning the sales of product " $X$ "

\begin{tabular}{|l|r|r|r|r|}
\hline Months & 2010 & 2011 & 2012 & 2013 \\
\hline January & 525 & 345 & 465 & 495 \\
\hline February & 1.110 & 900 & 1.260 & 1.125 \\
\hline March & 2.250 & 2.025 & 2.400 & 2.475 \\
\hline April & 3.150 & 3.375 & 2.130 & 3.225 \\
\hline May & 2.250 & 3.150 & 2.925 & 2.775 \\
\hline June & 2.625 & 2.625 & 3.450 & 2.400 \\
\hline July & 2.475 & 2.325 & 2.775 & 2.625 \\
\hline August & 1.800 & 1.800 & 2.100 & 1.350 \\
\hline September & 1.200 & 975 & 1.125 & 1.095 \\
\hline October & 825 & 600 & 825 & 900 \\
\hline November & 465 & 330 & 525 & 495 \\
\hline December & 225 & 180 & 180 & 210 \\
\hline \multicolumn{4}{|r|}{ Source: data from ALFA” production industrial company } \\
\end{tabular}


Graphic, the diagram of the sales evolution is presented in the following figure:

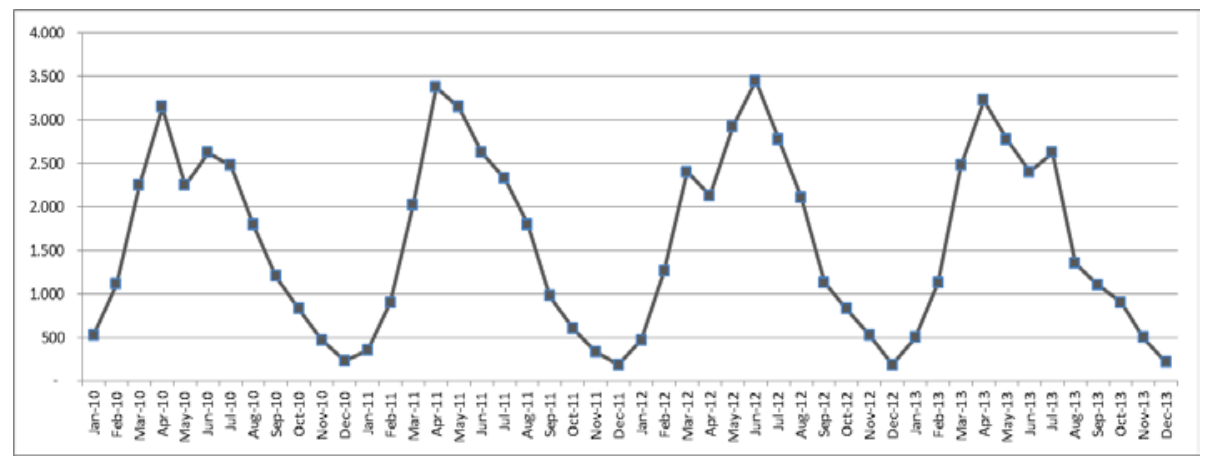

Figure 1 Diagram of the sales evolution

Source: own calculations, based on the historical data concerning the sales of product " $X$ ", for the period of time 2010-2013

The curve has a conical shape showing the seasonal evolution of the sales volume, the highest values being listed in the spring-summer months, and the lowest ones in the autumn-winter months.

In order to do the forecast for 2014, we must go through the following stages:

$\checkmark$ Calculating the total annual sales and the monthly average based on the real data:

Table 2 Total annual sales and the monthly averages

\begin{tabular}{|l|r|r|r|r|}
\hline Years & 2010 & 2011 & 2012 & 2013 \\
\hline Total annual sales & 18.900 & 18.630 & 20.160 & 19.170 \\
\hline Monthly sales average & 1.575 & 1.553 & 1.680 & 1.598 \\
\hline \multicolumn{2}{|c|}{ Source: data from „ALFA” production industrial company } \\
\hline
\end{tabular}

Setting the monthly total values for the whole year 2013:

Table 3 Monthly total values

\begin{tabular}{|l|c|}
\hline Months & $\begin{array}{c}\text { Monthly total values cumulated } \\
\text { for the year 2013 }\end{array}$ \\
\hline January & 495 \\
\hline February & 1.620 \\
\hline March & 4.095 \\
\hline April & 7.320 \\
\hline May & 10.095 \\
\hline June & 12.495 \\
\hline July & 15.120 \\
\hline August & 16.470 \\
\hline September & 17.565 \\
\hline October & 18.465 \\
\hline November & 18.960 \\
\hline Decembers & 19.170 \\
\hline
\end{tabular}

Source: own calculations, based on data from “ALFA” production industrial company 
Drawing up the Table of the moving totals for the year 2013:

Table 4 Table of the moving totals

\begin{tabular}{|l|c|}
\hline \multicolumn{1}{|c|}{ Months } & $\begin{array}{c}\text { Moving totals } \\
\text { for the year 2013 }\end{array}$ \\
\hline January & 20.190 \\
\hline February & 20.055 \\
\hline March & 20.130 \\
\hline April & 21.225 \\
\hline May & 21.075 \\
\hline June & 20.025 \\
\hline July & 19.875 \\
\hline August & 19.125 \\
\hline September & 19.095 \\
\hline October & 19.170 \\
\hline November & 19.140 \\
\hline December & 19.170 \\
\hline
\end{tabular}

Source: own calculations, based on data from “ALFA" production industrial company

$\checkmark$ The sales evolution is graphically presented based on the historical data (Table 1), as well as on the data concerning the Cumulated monthly totals (Table 3) and the table of the moving averages (Table 4).

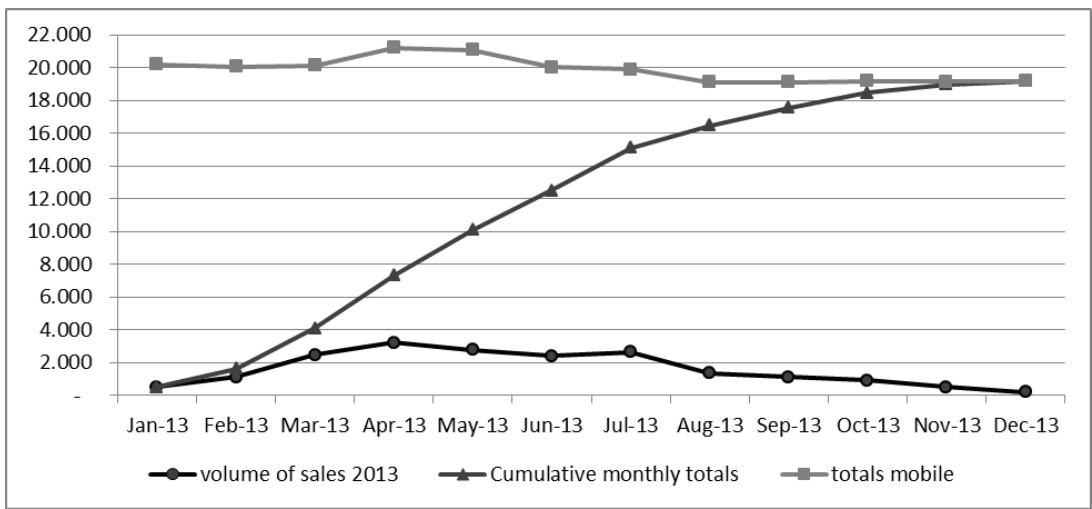

Figure 2 Graphical representation of the sales evolution

Source: own calculations, based on data from "ALFA" production industrial company

In order to determine the linear adjustment, we mark "xi" - the rank of the months of the four years and "yi" - the monthly sales (Table 1). Applying the method of least squares and determining the values of $\bar{x}$ and $\bar{y}$, we calculate the coefficient for the line "a" according to the formula:

$$
a=\frac{\sum_{i=1}^{n}\left(x_{i}-\bar{x}\right)\left(y_{i}-\bar{y}\right)}{\sum_{i=1}^{n} x_{i}{ }^{2}}
$$


Table 5 Calculations necessary for setting the coefficient of the linear adjustment according to the first calculation formula

\begin{tabular}{|c|c|c|c|c|c|}
\hline $\mathrm{xi}$ & yi & $\mathrm{xi}-\bar{x}$ & yi $-\bar{y}$ & $(\mathrm{xi}-\bar{x})(\mathrm{yi}-\bar{y})$ & $(x i-\bar{x})^{2}$ \\
\hline 1 & 525 & $-23,50$ & $-1.076,25$ & $25.291,88$ & 552,25 \\
\hline 2 & 1.110 & $-22,50$ & $-491,25$ & $11.053,13$ & 506,25 \\
\hline 3 & 2.250 & $-21,50$ & 648,75 & $-13.948,13$ & 462,25 \\
\hline 4 & 3.150 & $-20,50$ & $1.548,75$ & $-31.749,38$ & 420,25 \\
\hline 5 & 2.250 & $-19,50$ & 648,75 & $-12.650,63$ & 380,25 \\
\hline 6 & 2.625 & $-18,50$ & $1.023,75$ & $-18.939,38$ & 342,25 \\
\hline 7 & 2.475 & $-17,50$ & 873,75 & $-15.290,63$ & 306,25 \\
\hline 8 & 1.800 & $-16,50$ & 198,75 & $-3.279,38$ & 272,25 \\
\hline 9 & 1.200 & $-15,50$ & $-401,25$ & $6.219,38$ & 240,25 \\
\hline 10 & 825 & $-14,50$ & $-776,25$ & $11.255,63$ & 210,25 \\
\hline 11 & 465 & $-13,50$ & $-1.136,25$ & $15.339,38$ & 182,25 \\
\hline 12 & 225 & $-12,50$ & $-1.376,25$ & $17.203,13$ & 156,25 \\
\hline 13 & 345 & $-11,50$ & $-1.256,25$ & $14.446,88$ & 132,25 \\
\hline 14 & 900 & $-10,50$ & $-701,25$ & $7.363,13$ & 110,25 \\
\hline 15 & 2.025 & $-9,50$ & 423,75 & $-4.025,63$ & 90,25 \\
\hline 16 & 3.375 & $-8,50$ & $1.773,75$ & $-15.076,88$ & 72,25 \\
\hline 17 & 3.150 & $-7,50$ & $1.548,75$ & $-11.615,63$ & 56,25 \\
\hline 18 & 2.625 & $-6,50$ & $1.023,75$ & $-6.654,38$ & 42,25 \\
\hline 19 & 2.325 & $-5,50$ & 723,75 & $-3.980,63$ & 30,25 \\
\hline 20 & 1.800 & $-4,50$ & 198,75 & $-894,38$ & 20,25 \\
\hline 21 & 975 & $-3,50$ & $-626,25$ & $2.191,88$ & 12,25 \\
\hline 22 & 600 & $-2,50$ & $-1.001,25$ & $2.503,13$ & 6,25 \\
\hline 23 & 330 & $-1,50$ & $-1.271,25$ & $1.906,88$ & 2,25 \\
\hline 24 & 180 & $-0,50$ & $-1.421,25$ & 710,63 & 0,25 \\
\hline 25 & 465 & 0,50 & $-1.136,25$ & $-568,13$ & 0,25 \\
\hline 26 & 1.260 & 1,50 & $-341,25$ & $-511,88$ & 2,25 \\
\hline 27 & 2.400 & 2,50 & 798,75 & $1.996,88$ & 6,25 \\
\hline 28 & 2.130 & 3,50 & 528,75 & $1.850,63$ & 12,25 \\
\hline 29 & 2.925 & 4,50 & $1.323,75$ & $5.956,88$ & 20,25 \\
\hline 30 & 3.450 & 5,50 & $1.848,75$ & $10.168,13$ & 30,25 \\
\hline 31 & 2.775 & 6,50 & $1.173,75$ & $7.629,38$ & 42,25 \\
\hline 32 & 2.100 & 7,50 & 498,75 & $3.740,63$ & 56,25 \\
\hline 33 & 1.125 & 8,50 & $-476,25$ & $-4.048,13$ & 72,25 \\
\hline 34 & 825 & 9,50 & $-776,25$ & $-7.374,38$ & 90,25 \\
\hline 35 & 525 & 10,50 & $-1.076,25$ & $-11.300,63$ & 110,25 \\
\hline 36 & 180 & 11,50 & $-1.421,25$ & $-16.344,38$ & 132,25 \\
\hline 37 & 495 & 12,50 & $-1.106,25$ & $-13.828,13$ & 156,25 \\
\hline 38 & 1.125 & 13,50 & $-476,25$ & $-6.429,38$ & 182,25 \\
\hline 39 & 2.475 & 14,50 & 873,75 & $12.669,38$ & 210,25 \\
\hline 40 & 3.225 & 15,50 & $1.623,75$ & $25.168,13$ & 240,25 \\
\hline 41 & 2.775 & 16,50 & $1.173,75$ & $19.366,88$ & 272,25 \\
\hline 42 & 2.400 & 17,50 & 798,75 & $13.978,13$ & 306,25 \\
\hline 43 & 2.625 & 18,50 & $1.023,75$ & $18.939,38$ & 342,25 \\
\hline 44 & 1.350 & 19,50 & $-251,25$ & $-4.899,38$ & 380,25 \\
\hline 45 & 1.095 & 20,50 & $-506,25$ & $-10.378,13$ & 420,25 \\
\hline 46 & 900 & 21,50 & $-701,25$ & $-15.076,88$ & 462,25 \\
\hline 47 & 495 & 22,50 & $-1.106,25$ & $-24.890,63$ & 506,25 \\
\hline 48 & 210 & 23,50 & $-1.391,25$ & $-32.694,38$ & 552,25 \\
\hline 1.176 & 76.860 & - & - & $-49.500,00$ & $9.212,00$ \\
\hline
\end{tabular}


According to another formula, the coefficient for the line "a" can be determined as follows:

$$
a=\frac{\sum_{i=1}^{n} x_{i} \cdot y_{i}-n \cdot \bar{x} \cdot \bar{y}}{\sum_{i=1}^{n} x_{i}^{2}-n \cdot \overline{x^{2}}}
$$

Table 6 Calculations necessary for setting the coefficient of the linear adjustment according to the second calculation formula

\begin{tabular}{|c|c|c|c|c|c|c|c|}
\hline xi & yi & $\mathrm{xi}^{2}$ & $\mathrm{xi} \cdot \mathrm{yi}$ & xi & yi & $\mathrm{xi}^{2}$ & $\mathrm{xi} \cdot \mathrm{yi}$ \\
\hline 1 & 525,00 & 1,00 & 525,00 & 26 & $1.260,00$ & 676,00 & $32.760,00$ \\
\hline 2 & $1.110,00$ & 4,00 & $2.220,00$ & 27 & $2.400,00$ & 729,00 & $64.800,00$ \\
\hline 3 & $2.250,00$ & 9,00 & $6.750,00$ & 28 & $2.130,00$ & 784,00 & $59.640,00$ \\
\hline 4 & $3.150,00$ & 16,00 & $12.600,00$ & 29 & $2.925,00$ & 841,00 & $84.825,00$ \\
\hline 5 & $2.250,00$ & 25,00 & $11.250,00$ & 30 & $3.450,00$ & 900,00 & $103.500,00$ \\
\hline 6 & $2.625,00$ & 36,00 & $15.750,00$ & 31 & $2.775,00$ & 961,00 & $86.025,00$ \\
\hline 7 & $2.475,00$ & 49,00 & $17.325,00$ & 32 & $2.100,00$ & $1.024,00$ & $67.200,00$ \\
\hline 8 & $1.800,00$ & 64,00 & $14.400,00$ & 33 & $1.125,00$ & $1.089,00$ & $37.125,00$ \\
\hline 9 & $1.200,00$ & 81,00 & $10.800,00$ & 34 & 825,00 & $1.156,00$ & $28.050,00$ \\
\hline 10 & 825,00 & 100,00 & $8.250,00$ & 35 & 525,00 & $1.225,00$ & $18.375,00$ \\
\hline 11 & 465,00 & 121,00 & $5.115,00$ & 36 & 180,00 & $1.296,00$ & $6.480,00$ \\
\hline 12 & 225,00 & 144,00 & $2.700,00$ & 37 & 495,00 & $1.369,00$ & $18.315,00$ \\
\hline 13 & 345,00 & 169,00 & $4.485,00$ & 38 & $1.125,00$ & $1.444,00$ & $42.750,00$ \\
\hline 14 & 900,00 & 196,00 & $12.600,00$ & 39 & $2.475,00$ & $1.521,00$ & $96.525,00$ \\
\hline 15 & $2.025,00$ & 225,00 & $30.375,00$ & 40 & $3.225,00$ & $1.600,00$ & $129.000,00$ \\
\hline 16 & $3.375,00$ & 256,00 & $54.000,00$ & 41 & $2.775,00$ & $1.681,00$ & $113.775,00$ \\
\hline 17 & $3.150,00$ & 289,00 & $53.550,00$ & 42 & $2.400,00$ & $1.764,00$ & $100.800,00$ \\
\hline 18 & $2.625,00$ & 324,00 & $47.250,00$ & 43 & $2.625,00$ & $1.849,00$ & $112.875,00$ \\
\hline 19 & $2.325,00$ & 361,00 & $44.175,00$ & 44 & $1.350,00$ & $1.936,00$ & $59.400,00$ \\
\hline 20 & $1.800,00$ & 400,00 & $36.000,00$ & 45 & $1.095,00$ & $2.025,00$ & $49.275,00$ \\
\hline 21 & 975,00 & 441,00 & $20.475,00$ & 46 & 900,00 & $2.116,00$ & $41.400,00$ \\
\hline 22 & 600,00 & 484,00 & $13.200,00$ & 47 & 495,00 & $2.209,00$ & $23.265,00$ \\
\hline 23 & 330,00 & 529,00 & $7.590,00$ & 48 & 210,00 & $2.304,00$ & $10.080,00$ \\
\hline 24 & 180,00 & 576,00 & $4.320,00$ & 1.176 & $76.860,00$ & $8.024,00$ & $1.833 .570,00$ \\
\hline 25 & 465,00 & 625,00 & $11.625,00$ & & & & \\
\hline
\end{tabular}

Based on the data in the tables above, we calculate:

$$
\bar{x}=\frac{\sum_{i=1}^{n} x i}{n}=\frac{1.176}{48}=24,50 \text { and } \bar{y}=\frac{\sum_{i=1}^{n} y i}{n}=\frac{76.860,00}{48}=1.601,25
$$

Replacing with the calculated values, we can set $a=-5,37$.

The equation of the line is determined by the formula: $y-\bar{y}=a(x-\bar{x})$.

So, we obtain $y-1.601,25=-5,37(x-24,50)$ and hence $y=-5,37 \cdot x+1.732,82$.

$\checkmark$ We calculate the adjusted values for the period of time considered (2010-2013) based on the equation of the line determined previously.

Table 7 Table of the adjusted values

\begin{tabular}{|l|c|c|c|c|}
\hline \multirow{2}{*}{ Months } & \multicolumn{4}{|c|}{ Adjusted values for the years } \\
\cline { 2 - 5 } & 2010 & 2011 & 2012 & 2013 \\
\hline January & $1.727,45$ & $1.663,01$ & $1.598,57$ & $1.534,13$ \\
\hline February & $1.722,08$ & $1.657,64$ & $1.593,20$ & $1.528,76$ \\
\hline
\end{tabular}




\begin{tabular}{|l|l|l|l|l|}
\hline March & $1.716,71$ & $1.652,27$ & $1.587,83$ & $1.523,39$ \\
\hline April & $1.711,34$ & $1.646,90$ & $1.582,46$ & $1.518,02$ \\
\hline May & $1.705,97$ & $1.641,53$ & $1.577,09$ & $1.512,65$ \\
\hline June & $1.700,60$ & $1.636,16$ & $1.571,72$ & $1.507,28$ \\
\hline July & $1.695,23$ & $1.630,79$ & $1.566,35$ & $1.501,91$ \\
\hline August & $1.689,86$ & $1.625,42$ & $1.560,98$ & $1.496,54$ \\
\hline September & $1.684,49$ & $1.620,05$ & $1.555,61$ & $1.491,17$ \\
\hline October & $1.679,12$ & $1.614,68$ & $1.550,24$ & $1.485,80$ \\
\hline November & $1.673,75$ & $1.609,31$ & $1.544,87$ & $1.480,43$ \\
\hline December & $1.668,38$ & $1.603,94$ & $1.539,50$ & $1.475,06$ \\
\hline
\end{tabular}

Source: own calculations, based on data from "ALFA" production industrial company

We determine the seasonal coefficients, reporting the real sales values (Table 1) with the calculated adjusted values (Table 7):

Table 8 Seasonal coefficients

\begin{tabular}{|l|c|c|c|c|}
\hline \multirow{2}{*}{ Months } & \multirow{2}{*}{2010} & 2011 & 2012 & 2013 \\
\hline January & 0,303916 & 0,207455 & 0,290885 & 0,322658 \\
\hline February & 0,644569 & 0,542941 & 0,790861 & 0,735891 \\
\hline March & 1,310647 & 1,225587 & 1,511497 & 1,624666 \\
\hline April & 1,840663 & 2,049305 & 1,346006 & 2,124478 \\
\hline May & 1,318898 & 1,918941 & 1,854682 & 1,834529 \\
\hline June & 1,543573 & 1,604366 & 2,195047 & 1,592272 \\
\hline July & 1,459979 & 1,425689 & 1,771635 & 1,747775 \\
\hline August & 1,065177 & 1,107406 & 1,345309 & 0,902081 \\
\hline September & 0,712382 & 0,601833 & 0,723189 & 0,734323 \\
\hline October & 0,491329 & 0,371591 & 0,532176 & 0,605734 \\
\hline November & 0,277819 & 0,205057 & 0,339834 & 0,334362 \\
\hline December & 0,134861 & 0,112224 & 0,116921 & 0,142367 \\
\hline \multicolumn{2}{|l|}{ Source: own calculations, based on data from “ALFA” production industrial company }
\end{tabular}

Setting the correction coefficients, by reporting the total seasonal coefficients calculated for each month to the number of years considered, resulting the monthly average values for the four years:

Table 9 Correction coefficients

\begin{tabular}{|l|c|c|}
\hline Months & $\begin{array}{c}\text { Total seasonal coefficients } \\
\text { for the four years }\end{array}$ & $\begin{array}{c}\text { Correction } \\
\text { coefficients }\end{array}$ \\
\hline January & 1,124915 & 0,281229 \\
\hline February & 2,714262 & 0,678565 \\
\hline March & 5,672396 & 1,418099 \\
\hline April & 7,360451 & 1,840113 \\
\hline May & 6,927050 & 1,731762 \\
\hline June & 6,935259 & 1,733815 \\
\hline July & 6,405077 & 1,601269 \\
\hline August & 4,419973 & 1,104993 \\
\hline September & 2,771727 & 0,692932 \\
\hline October & 2,000829 & 0,500207 \\
\hline
\end{tabular}




\begin{tabular}{|l|l|l|}
\hline November & 1,157073 & 0,289268 \\
\hline December & 0,506373 & 0,126593 \\
\hline
\end{tabular}

Source: own calculations, based on data from "ALFA" production industrial company

Analyzing the evolution of sales during the four years, based on the calculations presented above, we can extrapolate the trend of the sales evolution. In order to forecast the sales volume for 2014, we mark the rank of the months from 49 to 60 and we calculate the adjusted values, which will be corrected afterwards using the correction coefficients, thus resulting the following values:

Table 10 Forecast values of the sales volume for 2014

\begin{tabular}{|l|c|c|c|c|}
\hline $\begin{array}{c}\text { Months } \\
\text { of } 2014\end{array}$ & xi & $\begin{array}{c}\text { Adjusted } \\
\text { values for 2014 }\end{array}$ & $\begin{array}{c}\text { Correction } \\
\text { coefficients }\end{array}$ & $\begin{array}{c}\text { Values for the sales } \\
\text { volume forecast for 2014 }\end{array}$ \\
\hline January & 49 & $1.469,69$ & 0,281229 & 413 \\
\hline February & 50 & $1.464,32$ & 0,678565 & 994 \\
\hline March & 51 & $1.458,95$ & 1,418099 & 2.069 \\
\hline April & 52 & $1.453,58$ & 1,840113 & 2.675 \\
\hline May & 53 & $1.448,21$ & 1,731762 & 2.508 \\
\hline June & 54 & $1.442,84$ & 1,733815 & 2.502 \\
\hline July & 55 & $1.437,47$ & 1,601269 & 2.302 \\
\hline August & 56 & $1.432,10$ & 1,104993 & 1.582 \\
\hline September & 57 & $1.426,73$ & 0,692932 & 989 \\
\hline October & 58 & $1.421,36$ & 0,500207 & 711 \\
\hline November & 59 & $1.415,99$ & 0,289268 & 410 \\
\hline December & 60 & $1.410,62$ & 0,126593 & 179 \\
\hline
\end{tabular}

Source: own calculations, based on data from “ALFA" production industrial company

Graphic, the diagram of the sales evolution, based on the historical data for the period of time 2010-2013 plus the sales volume forecast for 2014, is presented in the following figure:

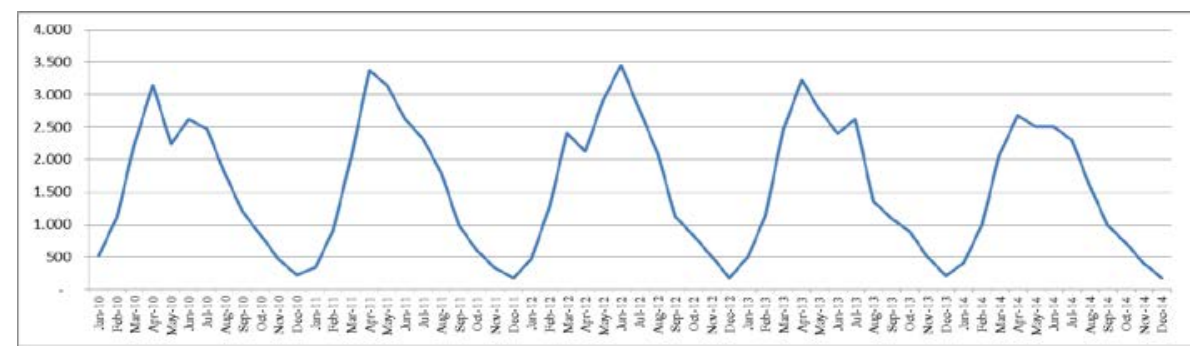

Figure 3 Diagram of the sales evolution

Source: own calculations, based on data from "ALFA" production industrial company

\section{Conclusions}

Business managers always had to pay attention to the efficient resource management, to that purpose using the planning and the budgets; it has become even more important in the current economic context. This period of crisis is regarded by some specialists as a recession stage of the economic cycle, thus a normal stage in the market economy. Consequently, it is natural that all the performance indicators should have loses. Under these conditions, we recommend drawing up a budget system, as it 
helps managers in achieving the strategic objectives they have set. While on decisionmaking level we use a scoreboard including the main budget indicators, on operational level we use the detailed budget.

The budget that influences all the other budgets is the sales budget. In order to sell, it is necessary to have a supply of goods which, in order to be produced, require raw materials, workforce, equipment, etc. Building the sales budget requires forecasting the sales volume (the sales programme) as well as the selling prices per unit. The specialized literature describes many sales forecasting methods. As to the preference of applying a certain method within a company, each method has advantages and disadvantages; however, in practice it was proved that a combination of several methods should be used. After setting the forecasted sales volume and associating it to the selling price per unit, the annual and the global forecasts for the sales budget on the level of the whole company, we can allocate the monthly and quarterly values, on groups of products or on groups of purchasers, also taking into consideration the seasonal variation.

The importance of building the sales budget lies in the fact that it later allows the exercise of control, the managers being subsequently able to decide on: the achievement of the forecasts in the next periods of time, changing the pricing policy, organizing promotional campaigns, training the employees, and so on.

\section{References}

Albu, N., Albu, C. (2003), Control de gestiune, vol. II, Bucharest, Editura Economică. Anthony, R. N., Govindarajan, V. (2007), Management Control Systems, Twelfth Edition, McGraw - Hill International Edition.

Bucur, I. A. (2007), Costurile producerii şi raportării informaţiei financiar-contabile, In Pătruţ, V. (ed.) Contabilitatea în contemporaneitatea românească (275284), EduSoft Publishing House, Bacău.

Caraiani, C., Dumitrana, M. (coord.) et al (2008), Contabilitate de gestiune şi control de gestiune, Ediţia a II-a, Bucharest, Editura Universitară.

Dumitru, C. G., Ioanăş, C. (2005), Contabilitatea de gestiune şi evaluarea performanţelor, Bucharest, Editura Universitară.

Gervais, M. (2005), Contrôle de gestion, 8e édition, Collection Gestion, Paris Economica.

Iacob, C., Ionescu, I. (1999), Controlul de gestiune la nivelul firmei, Bucharest, Editura Tribuna Economică.

Ionaşcu, I., Filip, A. T., Mihai, S. (2006), Control de gestiune, Ediţia a II-a, Bucharest, Editura Economică.

Rachlin, R. (2007), Sistemul complet de bugete ale firmei. Ghid practic şi formulare de lucru, Ediţia a II-a, Bucharest.

Solomon, D. C., Bucur, I. A. (2013), Aspects of Financial Equilibrium Analysis and Its Implications in Management Decisions, Studies and Scientific Researches Economics Edition, 18, 221-230, available at http://sceco.ub.ro/ index.php/SCECO/article/view/226.

Tabără, N., Tataru, S. et al (2009), Control de gestiune. Delimitări conceptuale, metode, aplicaţii, Iaşi, Editura TipoMoldova.

Tabără, N., Dragomirescu, S. E. (2009), Bugetul de vânzări - instrument al controlului de gestiune în contextual crizei economice actuale (partea I), Contabilitatea, expertiza şi auditul afacerilor, 9, 50-54.

Tabără, N., Dragomirescu, S. E. (2009), Bugetul de vânzări - instrument al controlului de gestiune în contextual crizei economice actuale (partea a II-a), Contabilitatea, expertiza şi auditul afacerilor, 9, 26-31. 